\title{
ECT for refractory secondary tourettism with dermatillomania following CO poisoning
}

\author{
Ahmed Naguy ${ }^{1 *}$, Pavly Samir ${ }^{2}$ and Ali Al-Tajali ${ }^{3}$ \\ *Correspondence: ahmednagy@hotmail.co.uk

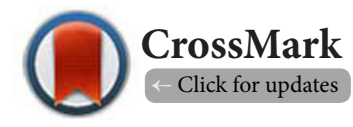 \\ ${ }^{1} \mathrm{CAP}$ Unit, Kuwait Centre for Mental Health (KCMH), Shuwaikh, State of Kuwait, Kuwait. \\ ${ }^{2}$ Emergency Psychiatry Unit, $\mathrm{KCMH}$, Kuwait. \\ ${ }^{3}$ Neuromodulation Unit, $\mathrm{KCMH}$, Kuwait.
}

\section{Correspondence}

'Secondary tourettism' is euphemistically applied to refer to tics with underlying causations or associations mostly affecting basal ganglia, contrasted with the commonest cause of tics, that is, de la Tourette syndrome [1]. Causes are legion [2] as in Table 1. Treatment modalities for tics are protean [3] with differing qualities of evidence-base. Table 2 summarizes available options. Electro-convulsive therapy (ECT) for treatment-resistant tics is limited to case reports in literature. These cases were quite complex, Tourette syndrome with comorbid major depression disorder, obsessive-compulsive disorder, or, self-injurious behaviours. Tics as catatonic signs were also reported in two cases including autism [4].

More than $30 \%$ of patients with acute carbon monoxide (CO) may experience delayed onset of neuropsychiatric sequelae including, inter alia, motor, cognitive, and, affective aftermath [5].

Data in literature speak to the idea that Hyperbaric Oxygen Therapy (HBOT) could mitigate or halt the progression of such complications [6].

Here, we are reporting a case of $\mathrm{CO}$ poisoning, presented to us with difficult-to-treat secondary tics and dermatillomania that responded ultimately to ECT. This could open new treatment venues in such complicated clinical scenarios.

\section{Case report}

A 36-year-old Indian fireman referred to our casualty from neurologic clinic for treatment-resistant tics and disfiguring skin-picking. He had a history of $\mathrm{CO}$ poisoning 3 weeks prior to the development of this movement disorder. He was treated then in ER receiving normobaric oxygen and dismissed. He had been tried sequentially on haloperidol $(2.5 \mathrm{mg} / \mathrm{d})$, but he developed acute dystonic reactions (torticollis and occulogyric crisis). He developed severe akathisia on low-dose aripiprazole ( $5 \mathrm{mg} / \mathrm{d})$. He couldn't tolerate clonidine $(100 \mu \mathrm{g} / \mathrm{d})$ for symptomatic hypotension and bradycardia. He got oversedated on clonazepam (1 mg/d). Levetiracetam (1000 mg/d), for a whole month, was tried, but, deemed futile and hence, was discontinued. Table 3 portrays medications chart.

There was no genetic load of neuropsychiatric illness. He was non-smoker with no history of use of illicit substances. No medical comorbidities were of relevance.

Neuro-radiology revealed bilateral hyperintense pallidal signals on MRI-T2WI. Differential [7] is shown in Table 4.

Yale-Global Tic Severity Scale (Y-GTSS) scored 85 (severe). Milwaukee Inventory for the Dimensions of Adult Skin Picking (MIDAS) read 27 for automatic subscale and 24 for focused subscale.

Across the interview, patient was markedly distressed by multiple motor (blinking, shoulder shrugging, and sniffing) and phonic tics (grunting). Trunk and arms were covered by multiple sores of excoriated skin, some were pustulated and oozing.

As the patient was demoralized with depressive overlay and endorsed passive death wishes, we opted for a course of ECT. Introducing an SSRI remained a viable option at that stage for both obsessive and depressive domains, but, the patient was too desperate and resistive to embark on a new medication trial. Modified bi-temporal ECT at $20 \%$ energy (up to $30 \%$ as sessions advanced) was administered using Thymetron device during this drug-free interlude. Six sessions were given (3 sessions/week) under general anaesthesia (using methohexital and suxamethonium) over a period of two weeks. Patient's mood soon brightened after 2 sessions only, tics significantly diminished by the $4^{\text {th }}$ session, and dermatillomania totally abated by the end of sessions. Y-GTSS was readministered and read 15. MIDAS scored 2 (for each subscale).

The response was well-sustained at follow-up weeks 4,8 , 12 and 16.

On week-8, fluvoxamine and sulpride were introduced to maintain ECT response and guard against possible relapse.

Impressive ECT response in our case goes in tandem with a number of case reports in literature [8-14]. These reports, however, capitalize on de la Tourette syndrome. To our knowledge, 
Table 1. Secondary tourettism.

\begin{tabular}{ll}
\hline $\begin{array}{l}\text { Infections } \\
\text { Drugs }\end{array}$ & $\begin{array}{l}\text { Von Economo's encephalitis, CJD, HD } \\
\text { Stimulants, L-dopa, phenytoin, antipsychotics } \\
\text { (tardive tics) }\end{array}$ \\
Toxins & CO poisoning \\
Developmental & $\begin{array}{l}\text { Static encephalopathy, MR } \\
\text { Others }\end{array}$ \\
& $\begin{array}{l}\text { Trauma, schizophrenia, phakomatosis, } \\
\text { neuroacanthocytosis, degenerative, (subcortical) } \\
\text { strokes }\end{array}$ \\
\hline
\end{tabular}

Table 2. Pharmacologic options in TS.

- Antipsychotics (haloperidol, pimozide, risperidone, ziprasidone, amisulpride...)

- DA depleters (tetrabenazine)

- $\alpha 2$ agonists(clonidine, guanfacine)

- BDZ (clonazepam)

- Anticonvulsants (topiramate)

- Dopaminomimetics (ropinirole)

Table 3. Medications chart prior to ECT.

\begin{tabular}{llll}
\hline Drug & Dose & Duration & Reason to discontinue \\
\hline Haloperidol & $2.5 \mathrm{mg}$ & 1 week & Acute dystonias \\
Aripiprazole & $5 \mathrm{mg}$ & 10 days & Severe akathisia \\
Clonidine & $100 \mu \mathrm{g}$ & 2 days & Hypotension \& Bradycardia \\
Clonazepam & $1 \mathrm{mg}$ & 5 days & Oversedation \\
Levetiracetam & $1000 \mathrm{mg}$ & 1 month & Lack of efficacy \\
\hline
\end{tabular}

Table 4. Basal Ganglia T2 hyperintensity.

\begin{tabular}{ll}
\hline Ischemic & Venous infarction \\
Toxic & CO poisoning \\
Neurodegenerative/Metabolic & $\begin{array}{l}\text { Wilson disease, HD, CJD, Leigh's } \\
\text { disease, extrapontine mylinolysis, } \\
\text { hypoglycaemia }\end{array}$ \\
Neoplastic & Lymphoma \\
\hline
\end{tabular}

this case is one of early reports demonstrating ECT effectiveness in secondary tourettism and dermatillomania.

Although definitive mechanism remains elusive, we can theorize that modulation of monoaminergic transmission by ECT is contributory.

\section{Competing interests}

The authors declare that they have no competing interests.

\section{Authors' contributions}

\begin{tabular}{|l|c|c|c|}
\hline Authors' contributions & AN & PS & AT \\
\hline Research concept and design & -- & $\checkmark$ & -- \\
\hline Collection and/or assembly of data & $\checkmark$ & -- & -- \\
\hline Data analysis and interpretation & -- & -- & -- \\
\hline Writing the article & $\checkmark$ & $\checkmark$ & -- \\
\hline Critical revision of the article & -- & -- & $\checkmark$ \\
\hline Final approval of article & -- & -- & $\checkmark$ \\
\hline Statistical analysis & -- & -- & -- \\
\hline
\end{tabular}

\section{Acknowledgement}

Authors express their deepest gratitude to Dr.Haya Al-Mutairi, Consultant Psychiatrist, and Director General of KCMH for supervising clinical work all through.

\section{Publication history}

Senior Editor: Gianluca Serafini, Sapienza University of Rome, Italy. Editor: Basant K. Puri, Hammersmith Hospital, UK. Received: 31-Jul-2015 Final Revised: 31-Aug-2015 Accepted: 01-Sep-2015 Published: 05-Sep-2015

\section{References}

1. Mejia NI and Jankovic J. Secondary tics and tourettism. Rev Bras Psiquiatr. 2005; 27:11-7. | Article | PubMed

2. Fahn S, Jankovic J and Hallett M. Principles and Practice of Movement Disorders. $2^{\text {ed }}$ ed. Elsevier Saunders. 2011.

3. Naguy A and Al-Tajali Ali. Valproate for the Treatment of Resistant Tourette Syndrome With Comorbid Trichotillomania: A Case Report. J Psychiatry. 2015; 18:286. I Pdf

4. Dhossche DM, Reti IM, Shettar SM and Wachtel LE. Tics as signs of catatonia: electroconvulsive therapy response in 2 men. J ECT. 2010; 26:266-9. | Article | PubMed

5. Neubauer RA, Neubauer $\mathrm{V}$ and Nu A K C et al. Treatment of Late Neurologic Sequelae of Carbon Monoxide Poisoning with Hyperbaric Oxygenation: a Case Series. J Am Phys Surg. 2006; 11:56-9. I Pdf

6. Lee HF, Mak SC, Chi CS and Hung DZ. Hyperbaric oxygen for carbon monoxide poisoning-induced delayed neuropsychiatric sequelae. Zhonghua Yi Xue Za Zhi (Taipei). 2001; 64:310-4. | Article | PubMed

7. Hegde AN, Mohan S, Lath $N$ and Lim CC. Differential diagnosis for bilateral abnormalities of the basal ganglia and thalamus. Radiographics. 2011; 31:5-30. | Article | PubMed

8. Dehning $\mathrm{S}$, Feddersen $\mathrm{B}$, Mehrkens $\mathrm{JH}$ and Muller N. Long-term results of electroconvulsive therapy in severe Gilles de la Tourette syndrome. J ECT. 2011; 27:145-7. | Article | PubMed

9. Eddy $\mathrm{CM}$, Rickards $\mathrm{HE}$ and Cavanna AE. Treatment strategies for tics in Tourette syndrome. Ther Adv Neurol Disord. 2011; 4:25-45. | Article | PubMed Abstract | PubMed Full Text

10. Strassnig M, Riedel $M$ and Muller $N$. Electroconvulsive therapy in a patient with Tourette's syndrome and co-morbid Obsessive Compulsive Disorder. World J Biol Psychiatry. 2004; 5:164-6. | Article | PubMed

11. Rajashree VC, Manjiri CD, Ivan SN and Alka VP. Gilles de la Tourette's syndrome successfully treated with electroconvulsive therapy. Indian J Psychiatry. 2014; 56:407-8. | PubMed Abstract | PubMed Full Text

12. Karadenizli D, Dilbaz $N$ and Bayam G. Gilles de la Tourette syndrome: response to electroconvulsive therapy. J ECT. 2005; 21:246-8. | Article | PubMed

13. Rapoport $M$, Feder $V$ and Sandor P. Response of major depression and Tourette's syndrome to ECT: a case report. Psychosom Med. 1998; 60:528-9. | Article | PubMed

14. Guo JN, Kothari JS, Leckman JF and Ostroff RB. Successful Treatment of Tourette Syndrome with Electroconvulsive Therapy: A Case Report. Biol Psychiatry. 2014. I Article | PubMed

\section{Citation:}

Naguy A, Samir P and Al-Tajali A. ECT for refractory secondary tourettism with dermatillomania following CO poisoning. J Psychiatry Brain Funct. 2015; 2:2. http://dx.doi.org/10.7243/2055-3447-2-2 